\title{
Evaluation of the Toxicity of Urea Using Allium cepa L. Assay
}

\author{
*Adeleke, Martina T. V. Goodlife, Eugenia. E. \\ Department of Plant Science and Biotechnology, Rivers State University, Nkpolu, Port Harcourt, Nigeria
}

\begin{abstract}
Considering the present abuse of fertilizer application today, an experiment was conducted to evaluate the toxic effects of urea on plants using the Allium cepa $\mathrm{L}$. assay. Onion bulbs were first placed in water for 48 hours to initiate root growth, then they were placed in different concentrations of urea $(0 \%, 0.005 \%, 0.01 \%, 0.025 \%, 0.05 \%)$ for 24 hours. Both macroscopic and microscopic parameters show the toxic effect of urea. Root length and root number dropped in value with increase in treatment concentration. Likewise, the actively dividing mitotic cells also reduced in number with treatment concentration, thus giving rise to a drop in the mitotic index and a corresponding increase in mitotic inhibition with increase in treatment concentration of urea. These results all gave rise to a visible drop in root mass of the onion bulbs.
\end{abstract}

Keywords: Urea, Allium cepa assay, toxicity, mitotic index

DOI: $10.7176 / \mathrm{JBAH} / 9-4-04$

\section{Introduction}

In recent years, due to rapid population growth and a continuous decline in the amount of cultivated land area, the rate of fertilizer application keeps on rising in order to obtain higher crop production in agriculture (Wang et al., 2010). This is because the use of chemical fertilizers to increase yield has been found to be effective only within the first few years, after which the land becomes less productive, thus demanding consistent use on a long-term basis (Ojeniyi et al, 2009; Zhang et al., 2009). Moreover, though the addition of nutrients found in fertilizer increases plant growth, too much of it can negatively affect their growth and overall health.

Large amounts of chemical fertilizers used during the peak season make both crop production quantity and quality to deteriorate. This is particularly the case with too much nitrogen.

Meanwhile, nitrogen is one of the major limiting elements that are essential for plant growth and development (Mostafa and Abo-Baker, 2010; Suriharn et al., 2011; Undie et al., 2012).

Of all the nitrogen fertilizers, Urea is the most widely used in the world because of its high solubility, high nitrogen content (46\%), low cost and ease in handling; and it accounts for over $50 \%$ of all nitrogen applied (Gilbert, 2006).

Urea (N-source) added in soil undergoes $\mathrm{N}$-transformations due to the presence of enzymes, microbes and soil microflora, resulting in the formation of ammonium/ammonia and finally nitrate through hydrolysis and nitrification, respectively (Kavita et al. 2013). The soil pH increases temporarily in areas were urea has been applied due to hydrolysis of the urea by urease enzymes (Clay et al. 1990), and thus, accumulation of NH3 produced induces NH3 toxicity. Ammonium and nitrate are known to be paradoxical ions; plants take up nitrogen in these two inorganic forms, but both can result in toxicity symptoms when used as an exclusive nitrogen source (Kavita et al. 2013).

Higher concentrations of ammonium inhibit seed germination and seedling germination. Another characteristic manifestation is the inhibition of primary root growth (Britto and Kronzucker 2002). Similarly, nitrate at higher concentrations represses lateral root development prior to activation of the lateral root meristem (Zhang and Forde 2000). Plant growth characters are controlled by cell division, which are affected by treatment with agrochemicals. However, the subtle danger of widespread use of such chemicals lies in the possibility of their causing mutation of somatic cells, resulting in the accumulation of heritable abnormal genes in the population or the formation of malignant cells in the individuals. The toxicants that act on deoxyribonucleic acid (DNA) cause damage to the genome, including alterations in the nucleic acids, and result in the modification or activation of a cell's genome; these toxicants are classified as "genotoxic". Genotoxic and cytotoxic effects of fertilizers on plants have been shown by Koca (2008) and Khaldi et al. (2012), respectively.

Generally, excessive amounts of chemical fertilizers are applied to vegetables for instance, in order to achieve a higher yield (Stewart et al., 2005). This is especially so with plants such as lettuce, spinach and Telfaria whose leaves are eaten and usually, there are harmful accumulation of nitrates and nitrites in these crops (Sönmez et al., 2007).

Farmers hardly use fertilizer based on the recommendation from authorities such as Soil Resource Development Institute (SRDI) and Department of Agriculture Extension (DAE). This is a general problem, and it might be due to lack of awareness, narrow access of farmers to soil testing facilities and/or inadequate motivation by extension people (Sultana et al., 2014).

In this study, the Allium cepa assay has been used to evaluate the cytotoxicity of Urea using mitotic index parameters and root growth. The A. cepa assay is an efficient test for in situ monitoring for toxicity of 
environmental contaminants, and has been widely used to study genotoxicity and cytotoxicity of pesticides and fertilizers (Ma et al., 1994; Fernandes et al., 2007; Kavita et al., 2013). It is considered an excellent material for the assay of chromosomal aberration following chemical treatment. Its root meristem represents a normal proliferating plant cell population that is sensitive to changes in environmental conditions. The $A$. cepa assay provides a rapid procedure for screening chemicals which pose as environmental hazards.

\section{Materials and methods}

Dry and medium onion (Allium cepa) bulbs of about the same size, were locally obtained. The loose scaly part of the onion bulbs were carefully peeled off and the dead roots at their base carefully scraped away without destroying the root primordia.

Fifteen onion bulbs (between 110-120g) were then placed on plastic containers filled with distilled water so that only the base of the bulbs touch the distilled water for 48 hours to induce root growth, and also to determine the viability of the onions. The level of the water was maintained in each container so that the roots were always in contact with water. After 48 hours in water, the number of roots per onion bulb was recorded, and three roots from each onion bulb were colour-labelled to identify them, and their lengths recorded.

The cytotoxicity of urea was evaluated using Allium cepa assay. The different concentrations of urea in distilled water used were: $0 \%, 0.005 \%, 0.01 \%, 0.025 \%$ and $0.05 \%$. The Control contained only distilled water.

After 48 hours in water, the onion bulbs were transferred into containers with the different treatments, each replicated three times. The set up was kept in the dark at room temperature. After 24 hours in the different treatments, the number of roots per onion bulb were recorded again, and the lengths of the labelled roots noted. A few roots were immediately harvested from each bulb with forceps from the base of the onion between 11 am and $1 \mathrm{pm}$ (Ambrocio and Ian, 2011). The roots were fixed immediately in Carnoy's fluid (1 part of glacial acetic acid : 3 parts of ethanol) and placed in a refrigerator for 24 hours at $4^{\circ} \mathrm{C}$. The roots were then preserved in $70 \%$ ethanol in the refrigerator until use.

\section{Slide Preparation}

The onion roots were taken out of ethanol, rinsed and dried on filter paper.

The root tips were hydrolyzed in $1 \mathrm{~N}$ hydrochloric acid in a water bath at $60^{\circ} \mathrm{C}$ for 5 minutes to soften cell walls and make the root tip malleable. Then they were rinsed, dried and placed in a solution of $1 \%$ Ferric Chloride for one hour before slide preparation. Squashes were made in a drop of acetocarmine stain, and viewed under a compound light microscope. The mitotic study was carried out on temporary slides by observing the dividing cells and different types of division anomalies under low and high magnification. Photomicrographs were taken with a Samsung digital camera using an $\mathrm{x} 40$ objective.

The mitotic index for each treatment was calculated as follows:

Mitotic index $=$ Number of dividing cells $\times 100$

Total number of cells observed

\section{Results}

\section{Macroscopic Parameters}

The evaluation test on the effect of urea on Allium cells show that after 24 hours of the urea treatment, the Control had the highest values for root number (Table 1) and net root length (Table 2); and these values dropped with increase in Urea concentration.

Table 1: Onion root number before and after Urea treatment

\begin{tabular}{llll}
\hline $\begin{array}{l}\text { Urea concentrations } \\
(\%)\end{array}$ & $\begin{array}{l}\text { After 48hrs in water, } \\
\text { Average Root number }\end{array}$ & $\begin{array}{l}\text { After 24hrs in treatment, } \\
\text { Average Root number }\end{array}$ & $\begin{array}{l}\text { Net root } \\
\text { number }\end{array}$ \\
\hline Control & $78.33 \pm 13.80$ & $96.00 \pm 15.13$ & 17.67 \\
0.005 & $78.00 \pm 4.00$ & $88.33 \pm 5.51$ & 10.33 \\
0.01 & $64.67 \pm 8.08$ & $73.00 \pm 10.54$ & 8.33 \\
0.025 & $62.00 \pm 14.18$ & $69.00 \pm 14.00$ & 7.00 \\
0.05 & $69.33 \pm 10.26$ & $73.00 \pm 10.58$ & 3.67 \\
\hline
\end{tabular}


JBAH

Table 2: Onion root length before and after Urea treatment

\begin{tabular}{llll}
\hline $\begin{array}{l}\text { Urea concentrations } \\
(\%)\end{array}$ & $\begin{array}{l}\text { After 48hrs in water, } \\
\text { Average Root length } \\
(\mathrm{cm})\end{array}$ & $\begin{array}{l}\text { After 24hrs in treatment, } \\
\text { Average Root length } \\
(\mathrm{cm})\end{array}$ & $\begin{array}{l}\text { Net increase in root } \\
\text { length }(\mathrm{cm})\end{array}$ \\
\hline Control & $2.11 \pm 0.05$ & $3.05 \pm 0.68$ & 0.94 \\
0.005 & $2.47 \pm 0.07$ & $3.04 \pm 0.02$ & 0.57 \\
0.01 & $2.59 \pm 0.03$ & $2.99 \pm 0.02$ & 0.40 \\
0.025 & $2.87 \pm 0.12$ & $3.21 \pm 0.07$ & 0.34 \\
0.05 & $2.77 \pm 0.06$ & $2.98 \pm 0.09$ & 0.21 \\
\hline
\end{tabular}

Fig. 1 below shows the difference in root mass dropping drastically with treatment, even with the lowest treatment concentration. There appears however not to be as much difference in effect between treatment concentrations, except for the onion bulb in the highest concentration that is most affected and has very small root mass.

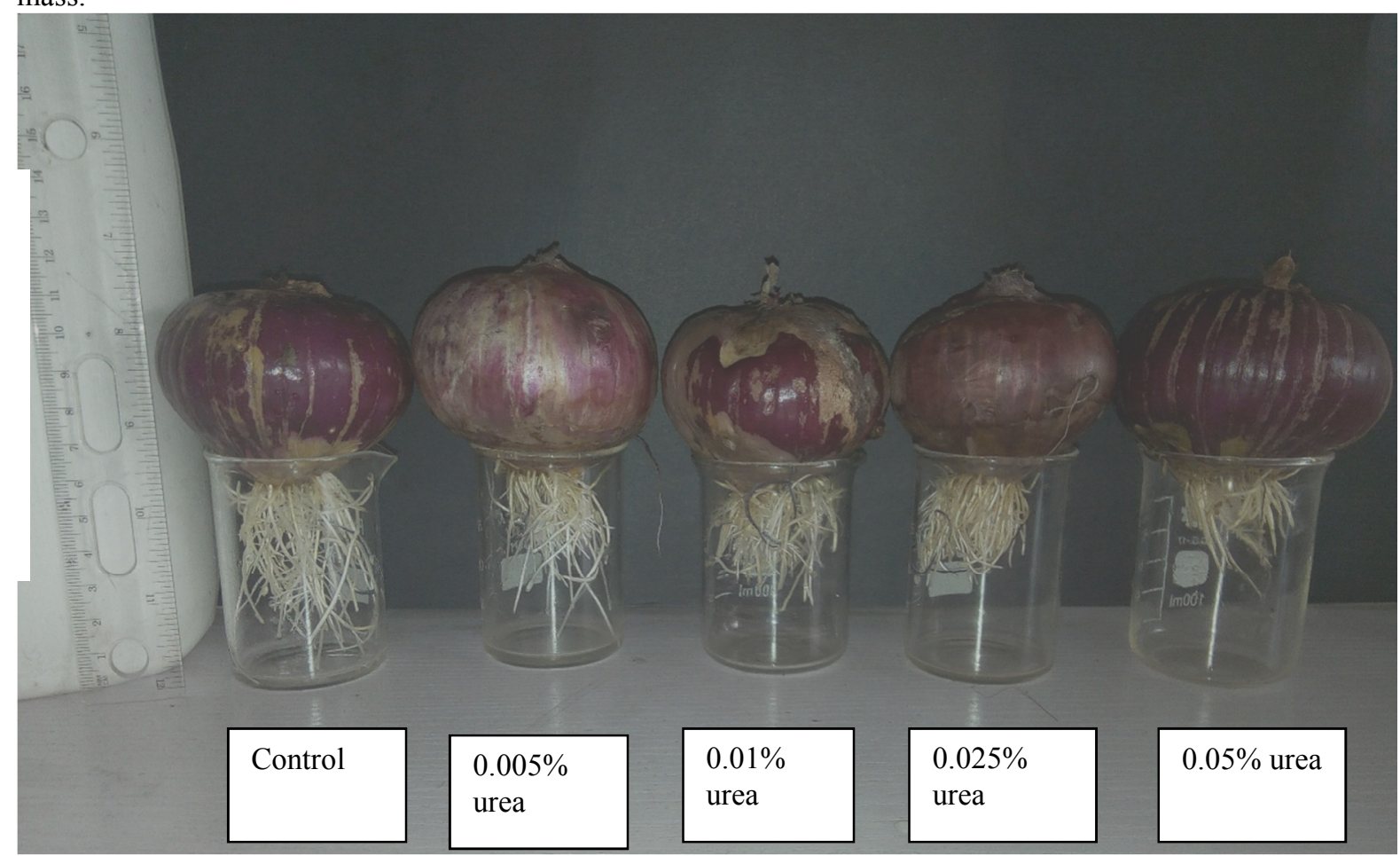

Fig. 1: Onion root growth response to treatment concentrations of urea

\section{Microscopic Parameters}

It was observed that the number of dividing cells per microscopic field decreased with increasing concentration of urea (Table 3). In addition, some abnormal mitotic stages were also observed in the treatment concentrations, especially in the highest (0.05\%); they include: anaphase bridges, laggards, and aberrant metaphase and anaphase cells (Fig. 2).
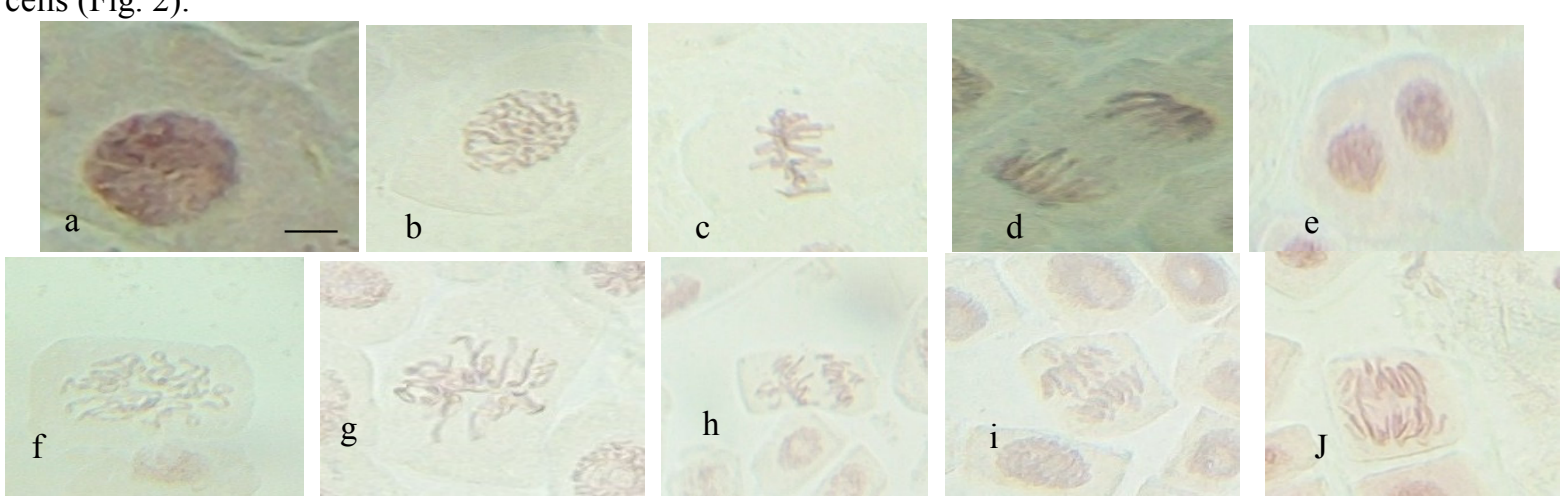

Figure 2: (a-e) normal stages of mitosis (a) interphase (b) prophase (c) metaphase (d) anaphase (e) telophase (f-J) aberrant mitotic stages (f) chromosome fragmentation at metaphase (g) scattered metaphase (h and i) precocious movement of chromosomes at anaphase $(\mathrm{j})$ anaphase bridge $(\mathrm{a}-\mathrm{j}, \mathrm{bar}=25 \mu \mathrm{m})$ 
Table 3: Mitotic indices and mitotic inhibition of onion root tips showing treatment effect

\begin{tabular}{llc}
\hline $\begin{array}{l}\text { Treatment } \\
\text { (\%of urea) }\end{array}$ & $\begin{array}{l}\text { Mitotic index } \\
(\%)\end{array}$ & $\begin{array}{c}\text { Mitotic Inhibition } \\
(\%)\end{array}$ \\
\hline Control & $51.18 \pm 0.56$ & - \\
0.005 & $36.31 \pm 0.98$ & 29.05 \\
0.01 & $22.22 \pm 0.72$ & 56.58 \\
0.025 & $15.17 \pm 0.84$ & 70.36 \\
0.05 & $8.55 \pm 0.63$ & 83.29 \\
\hline
\end{tabular}

The mitotic index shows a reduction in value with increase in treatment concentration (Table 3). Likewise, mitotic inhibition increased with treatment concentration.

\section{Discussion}

The toxicity of urea on plants, even at the relatively low concentrations used in this study $(0.005 \%-0.05 \%)$, was demonstrated using the Allium cepa assay. Urea affected negatively the root length and number with increasing concentration (Table 1and 2). Root lengths and root numbers decreased with increasing concentrations of urea that the onion bulbs were exposed to. The mitotic indices likewise dropped and mitotic inhibition increased with increase in treatment concentration (Table 3). The inhibition of primary root growth by inhibiting cell elongation and division are ammonium/ammonia toxicity symptoms as reported by Qin et al. (2011) in Arabidopsis. Similarly, work done by Kavita et al. (2013) indicate that the average root length and number of onion bulbs reduce with increasing concentrations of urea. The treatment concentrations of urea affected the number of roots of the onion bulbs they were exposed to significantly.

In addition to inhibiting seed germination and seedling germination, higher concentrations of ammonium inhibit primary root growth (Britto and Kronzucker 2002). Similarly, nitrate at higher concentrations represses lateral root development prior to activation of the lateral root meristem (Zhang and Forde 2000).

The meristematic regions of onion roots are very sensitive as it is the region of water absorption and mineral uptake. So, even at the relatively low concentrations of urea used in this study, the negative effect can be seen in the root mass development of the onion bulbs (Fig. 1). Therefore, it can be deduced that toxic substances, such as urea, coming in direct contact with dividing cells, can negatively affect the mitotic index of onion roots, and can have deleterious effects on plants, and may also affect the consumers of the affected plants, especially leaves. The most common chromosomal aberration observed with the treatments were irregular metaphase chromosomes, precocious movement of anaphase chromosomes and bridges (Fig. 2). Plant growth characters are controlled by cell division, which are affected by treatment with agrochemicals. However, the subtle danger of widespread use of such chemicals lies in the possibility of their causing mutation of somatic cells, resulting in the accumulation of heritable abnormal genes in the population or the formation of malignant cells in the individuals.

The fertilizer urea is a low cost, high N (46\%) containing fertilizer. Urea hydrolyses to yield $\mathrm{NH}_{4}{ }^{+}$and carbon dioxide. Uptake of $\mathrm{NH}_{4}{ }_{4}$ by plants releases $\mathrm{H}^{+}$which lowers the $\mathrm{pH}$ of the rhizosphere, leaving it acidic (Bindraban et al. 2015). Higher levels of $\mathrm{NH}_{4}^{+}$generate salinity stress as it reduces the uptake of other cations due to cation competition (Speer and Kaiser 1994; Britto and Kronzucker 2002; Britto and Kronzucker 2013). When $\mathrm{NH}_{4}{ }^{+}$is supplied as prime $\mathrm{N}$ source, many plant species being sensitive, developed toxicity symptoms (Kronzucker et al. 2001; Lanquar et al. 2009; Rogato et al. 2010).

Plant injury has been traced to ammonia derived from organic sources such as urine, chicken manure and animal manure (Zhou et al, 2000). In addition, inorganic sources such as ammonium salts have been reported to be injurious to plants when placed too close to the root zone (Britto and Kronzucker 2002).

\section{Conclusion and Recommendation}

The toxicity of urea, even at relatively low concentrations, when in direct contact with the roots of onion, has been established in this study. The damage would definitely be much more at higher concentrations. With the indiscriminate application of fertilizers that is common today, more so, at peak seasons for different crops, especially leafy vegetables such as Telfaria, abuse is imminent. This is because nitrogen is a major nutrient requirement for the production of leafy vegetables. When there is a high nitrogen supply in leafy vegetable crops, nitrogen mobile form concentrations (i.e., nitrate, ammonium) increase in leaves, thus becoming hazardous to human health. A high-nitrate diet is an important factor in the development of several human diseases such as methahemoglobinaemia, and gastric and bladder cancer (Parks et al., 2012).

Plants grown with high levels of Nitrogen fertilizer consist of carcinogenic substances such as nitrosamines, especially plants such as lettuce, spinach and Telfaria occidentalis whose leaves are eaten, and usually there are harmful accumulation of nitrates and nitrites in these crops (Sönmez et al., 2007).

It is recommended that farmers seek alternative long term methods of increasing soil nutrient content for plant growth as chemical fertilizers are detrimental to soils, plants, the environment and humans. Moreover, application of organic manure significantly impacts the physical, biological and chemical properties of the soils better, and 
this is mostly due to increased soil organic matter content from manure application. Organic manure provide the major plant nutrients and many of the required secondary nutrients as well.

Soil testing, which is a valuable tool for determining the fertilizer inputs required for efficient and economic production, should be carried out.

Where the use of inorganic fertilizers (for example urea) to improve crop yield must be used, direct contact with the plant roots should be avoided; and it should be controlled or supervised by agricultural extension workers.

\section{References}

Ambrocio Melvin A. Matias and Ian Kendrich C. Fontanilla (2011). Optimizing the Utility of Allium cepa L. var. aggregatum (sibuyas Tagalog) for the Allium Test by Elucidating its Mitotic Periodicity and Rhythmicity Under Varying Light Conditions, Science Diliman 23:1, 43-51

Bindraban, P.S., Dimkpa, C., Nagarajan, L. Roy, A. and Rabbinge, R. (2015) Revisiting fertilizers and fertilization strategies for improved nutrient uptake by plants. Biol and Fertility of Soils 51(8): 897911.

Britto, D. T., and Kronzucker, H. J. (2002). NH4+ toxicity in higher plants: a critical review. Journal of Plant Physiology 159: 567-584.

Britto, D. T. and Kronzucker, H. J. (2013). Ecological significance and complexity of N- source preference in plants. Annals of Botany 112(6): 957-963

Clay D. E., Malzer G.L., Anderson J. L. (1990). Ammonia volatilization from urea as influenced by soil temperature, soil water content, and nitrification and hydrolysis inhibitors. Soil Science Society of America Journal, 54(1):263-268.

Fernandes T. C. C., Mazzeo D. E. C., Marin-Morales M. A. (2007). Mechanism of micronuclei formation in polyploidizated Allium cepa exposed to trifluralin herbicide. Pesticide cells of Biochemistry and Physiology. 88 (3):252-259.

Gilbert PM, Harrison J, Heil C, Seitzinger S. (2006). Escalating worldwide use of urea-a global change contributing to coastal eutrophication. Biogeochemistry. 77(3):441-463.

Kavita Arora, Namrata Singh, Shipra Srivastava, and Alka Srivastava (2013). Evaluation of Genotoxic Risks Due to Temporal Changes in Soil Urea: Using Allium cepa L. Root Tip Bioassay. Cytologia 79(1): 85-93.

Khaldi, F., Berrebbah, H., and Djebar, M. R. (2012). Toxic effect of fertilizers on inferior plants resed as biological models. In: Proc. International Conference on Applied Life Sciences (ICALS 2012), Turkey. pp. 205-210.26

Koca, S. (2008). The cytogenetic effects of Sheffer A: a liquid fertilizer and growth regulator in root tip cells of Vicia faba L. Boston University Journal of Science and Technology 4.1: 121-126.

Kronzucker, H. J., Davenport, D. R. J. and Tester, M. (2001) Ammonium toxicity and the real cost of transport. Trends in Plant Science 6(8): 335-7.

Lanquar, V., Loque, D., Hormann, F., Yuan L., Bohner, A., Engelsberger, W. R., Lalonde, S., Schulze, W. X., Wiren, N. and Frommer, W. B. (2009) Feedback Inhibition of Ammonium Uptake by a Phospho-Dependent Allosteric Mechanism in Arabidopsis. The Plant Cell Nov 2009, 21 (11) 3610-3622

Ma, T. H., Cabrera G. L., Cebulska-Wasilewska A., Chen R., Loarca F., Vandererg A. L., Salamone M. F. (1994). Tradescantia-Stamen-Hair Mutation Bioassay- A collaborative study on Plant Genotoxicity Bioassays for the International Programme on Chemical safety, WHO, The United Nations. Mutation Research, 310: 211-220.

Mostafa, G.G. and A.A. Abo-Baker, (2010). Effect of bio and chemical fertilization on growth of sunflower (Helianthus annuus L.) at South valley area. Asian Journal of Crop Science, 2: 137-146.

Ojeniyi S. O., Owolabi O., Akinola, O. M. and Odedina S. A. (2009). "Field Study of Effect of Organomineral fertilizer on maize growth yield, soil and plant nutrient composition in Ilesa, Southwest Nigeria", Nigeria Journal of Soil Science, 19: 11-16.

Parks, S.E., Irving, D.E., Milham, P.J. (2012). A critical evaluation of on-farm rapid tests for measuring nitrate in leafy vegetables. Scientia Horticulturae, 134: 1-6.

Qin, C., Yi, K. K., and Wu, P. (2011). Ammonium affects cell viability to inhibit root growth in Arabidopsis. Journal of Zheijang University Science B-Biomedicine and Biotechnology 12: 477-484.

Rogato, A., D’Apuzzo, E. and Chiurazzi, M. (2010) The Multiple Plant Response to High Ammonium conditions; The Lotus japonicus AMTI; 3 protein acts as a putative transceptor. Plant Signaling and Behaviour 5(12): 1594-1596

Sönmez, I., Kaplan, M. and Sönmez, S. (2007). "An investigation of seasonal changes in nitrate contents of soils and irrigation waters in greenhouses located in antalya-demre region," Asian Journal of Chemistry, 19(7): 5639-5646.

Speer, M. and Kaiser, W. M. (1994) Replacement of nitrate by ammonium as the nitrogen source increases the salt sensitivity of pea plants.II.Inter- and intracellular solute compartmentation in leaflets. Plant Cell and environment 17(11): 1223-1231

Stewart, W.M.; Dibb, D.W.; Johnston, A.E.; Smyth, T.J. (2005)."The Contribution of Commercial Fertilizer 
Nutrients to Food Production". Agronomy Journal 97: 1-6.

Sultana, J.; Siddique, M.N.A.; Abdullah, M.R. (2014). Fertilizer recommendation for Agriculture: Practice, practicalities and adaptation in Bangladesh and Netherlands. International Journal Business Management and Social Research 1: 21-40

Suriharn, B., J. Sanitchon, P. Songsri and T. Kesmala, (2011). Effects of pruning levels and fertilizer rates on yield of physic nut (Jatropha curcas L.). Asian Journal of Plant Science, 10: 52-59.

Undie, U.L., D.F. Uwah and E.E. Attoe, (2012). Growth and development of late season maize/soybean intercropping in response to nitrogen and crop arrangement in the forest agro-ecology of South Southern Nigeria. International Journal of Agricultural Research, 7: 1-16.

Wang B. R., Cai Z. J., Li D. C. (2010). Effect of different long-term fertilization on the fertility of red upland soil. Journal of Soil and Water Conservation 24: 85-88.

Zhang, H., and Forde, B. G. (2000). Regulation of Arabidopsis root development by nitrate availability. Journal of Experimental Botany 51: 51-59.

Zhang H. M., Wang, B. R., Xu, M. G., Fan, T. L. (2009). Crop Yield and soil responses to long-term fertilization on a red soil in Southern China. Pedosphere, 19: 119-207.

Zhou Z.Y., Wang M.J., Wang J.S. (2000). Nitrate and nitrite contamination in vegetables in China, Food Reviews International, volume 16: 61-76. 